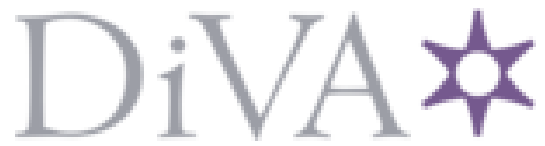

http://www.diva-portal.org

This is the published version of a paper published in Vegetation History and Archaeobotany.

Citation for the original published paper (version of record):

Nordlund, C. (2018)

Four points on Lennart von Post and the invention of "Pollen Statistics"

Vegetation History and Archaeobotany, 27: 311-317

https://doi.org/10.1007/s00334-017-0628-9

Access to the published version may require subscription.

N.B. When citing this work, cite the original published paper.

Permanent link to this version:

http://urn.kb.se/resolve?urn=urn:nbn:se:umu:diva-142754 


\title{
Four points on Lennart von Post and the invention of "Pollen Statistics"
}

\author{
Christer Nordlund ${ }^{1}$
}

Received: 3 April 2017 / Accepted: 15 July 2017 / Published online: 31 July 2017

(c) The Author(s) 2017. This article is an open access publication

\begin{abstract}
This essay is a contribution to the historiography of Lennart von Post and the early development of quantitative pollen analysis. Based on von Post's own publications and source material from the archives of Stockholm University College, where he was appointed professor in 1929, the essay offers four points on von Post's scientific identity and the collective work through which quantitative pollen analysis, or "pollen statistics", came into being. The four points are, first, that von Post made his career as a geologist; second, that he framed pollen analysis as a means to tackle Quaternary geological issues; third, that his work benefitted from collective work, both in the field and in the laboratory; and fourth, that quantitative pollen analysis was not accepted without criticism, taking some years to break through beyond the Geological Survey, where von Post worked before he became professor.
\end{abstract}

Keywords Lennart von Post $\cdot$ Historiography $\cdot$ Pollen analysis $\cdot$ Quaternary geology $\cdot$ Peat bog geology

\section{Introduction}

I first came across the name Lennart von Post (1884-1951) some 20 years ago when I was writing a $\mathrm{PhD}$ Thesis on the intellectual history of shoreline displacement in the Baltic Sea region (Nordlund 2001a), in which von Post features as one of the scientists who in the 1920s concluded that the changing relationship between land and sea in the past was not a question of isostasy (due to ice-related depression or rebound of land surface) or eustasy (due to global icemelting), but rather of both (von Post 1929). From this perspective, von Post represents the resolution of an extensive debate in the history of Scandinavian Quaternary geology that began in the middle of the 19th century, partly initiated by the work of von Post's distant relative Hampus von Post (1822-1911) (Frängsmyr 1976).

In the history of quantitative pollen analysis, on the other hand, the name Lennart von Post clearly represents a beginning. The now classic article 'Forest Tree Pollen in South Swedish Peat Bog Deposits' (von Post 1918, 1967),

Communicated by K. J. Edwards.

Christer Nordlund

christer.nordlund@umu.se

1 Department of Historical, Philosophical and Religious Studies, Umeå University, 90187 Umeå, Sweden expanding on a lecture that von Post presented at the 16th Convention of Scandinavian Naturalists in Kristiania (now Oslo) in 1916, is for good reason considered a starting point for stratigraphic palynology and palaeoecology (Manten 1967; Erdtman 1967; Brown 1991). It was, in short, the reason why we celebrated the centenary of pollen analysis in 2016 at the Royal Swedish Royal Academy of Sciences, an institution of which von Post himself was a proud member (Edwards et al. 2017).

Although the principles put forward in von Post's paper have been of seminal value for the development of palynology and other fields of research, it is important-from a history of science point of view-to remember that von Post himself was not a "palynologist" (the term itself was not coined until the 1940s), nor was he the only person behind this methodological innovation in the lab-field border zone (Kohler 2002). In this essay, I will make four points in an attempt to shed light on Lennart von Post's scientific identity as well as the collective work through which quantitative pollen analysis, or "pollen statistics", came into being. By doing this, I hope to demonstrate how the history of Quaternary geology and the early history of pollen analysis overlap. 


\section{Materials and methods}

This is an essay in history of science. It is based mainly on von Post's own publications, from 1909 to 1929, through which both his early career and the invention of pollen analysis as a quantitative method are traced. Von Post's research is furthermore analysed in the context of the Quaternary geology enterprise, but also as part of a national project to secure domestic energy supply during the Great War. The narrative about the appointment of von Post as Professor of General and Historical Geology at Stockholm University College is based on documents in Series FII AA Handlingar rörande lärares tillsättande (Vol. 70 and 71) and Series A1A Styrelseprotokoll (Vol. 33), Stockholm University College Archive, Swedish National Archives, Stockholm.

\section{Lennart von Post was a geologist}

Majoring in geology at Uppsala University, where he also studied some botany and comparative archaeology (within his licentiate), Lennart von Post was one of many actors in the interdisciplinary Quaternary geology enterprise in Scandinavia at the beginning of the 20th century. The main aim of this enterprise was, in short, to explore and describe how the natural (and early cultural) landscape had evolved since the latest Ice Age; how nature-with ice, water and the successive colonization of flora and fauna-had "created" the different countries (Eriksson 1978; Nordlund 2001a).

In the early part of his career, between 1908 and 1929, von Post was an employee of the Swedish Geological Survey, a government institution founded in order to map the country's geology and related natural resources (Nordlund 2007). He conducted several studies in both practical and theoretical geology, but first and foremost he was assigned the task of charting and analysing peat bogs from economic and Quaternary geological points of view. This was an undertaking that fitted his expertise well; peat bogs were the main object of his graduate studies, which earned him a licentiate in geology in 1907.

It was in this capacity, as a government geologist, that von Post attended the 16th Convention of Scandinavian Naturalists in Kristiania in 1916 and presented his novel quantitative method for analysis of the content of pollen in peat bogs, published 2 years later in Swedish in the conference proceedings as Skogsträdpollen i sydsvenska torvmosselagerföljder (Lundqvist 1951; Selling 1951). He was 32 years old by then and well on his way to making a name for himself in the scientific world, although it took some time before he managed to find a permanent academic position.

Ten years later, in November 1926, Stockholm University College announced its chair in geology, renamed as a professorship of "General and Historical Geology". Not yet a university, the college was a lively academic environment, garnering a strong research reputation regarding the study of the Quaternary, including climate change. The retired chair was the famous explorer and politician Gerard De Geer (1858-1943), who made weighty contributions to the study of shoreline displacement and glaciology and eventually developed a new Quaternary timescale, or "geochronology", based on varved sediments (Nordlund 2001a; Oldroyd 2006). Von Post's friend Hans Ahlmann (1889-1974), focusing on geomorphology and climate research in the North Polar Region, was trained at the college and became its professor of geography in 1929 (Sörlin 2011) and some years later, world-renowned meteorologist Carl-Gustaf Rossby (1898-1957) became professor there as well (Kristiansen 2017).

The new position in General and Historical Geology attracted four applicants, von Post being one of them. The others were Ernst Antevs (1888-1974), a former student of De Geer and docent in geology at the College; Gustaf Frödin (1883-1862), docent and Acting Professor of Geology and Mineralogy at Uppsala University; and Gustaf Troedsson (1891-1954), docent at Lund University as well as Acting Professor of Geology at the College since 1924. As the competition was tough it is not surprising that the university had difficulty choosing the best candidate for the job. Furthermore, von Post's academic merits were quite restricted in comparison with the other candidates; on the one hand, he was a famous peat bog geologist, on the other hand, he had no PhD or formal teaching experience. Through this administrative political matter, it is possible to get a glimpse of the scientific community's view of von Post and his work.

Four senior geologists from Sweden (Axel Gavelin and Karl Grönwall), Norway (Olaf Holtedahl) and Denmark (Victor Madsen) were engaged as external experts to evaluate the applications, three of whom clearly concluded that von Post was the right man. Their argument was, in brief, that von Post was not only the most productive of the four but also a geologist who had made a truly remarkable contribution to his field-the invention of statistical pollen analysis - that had created a "school" of great significance for other fields of research as well. Only one of the experts, Madsen, had a partly different opinion. He praised the invention of pollen analysis as a "groundbreaking" contribution to Quaternary geology, but claimed that von Post was too specialized for the position, favouring Troedsson instead. A fifth expert was enrolled (Carl Wiman) solely in order to review Troedsson's palaeontology research, which was found to be impressive.

The applicants, their applications, the experts and their extensive reviews were considered throughout the spring of 1929, first at the Faculty of Mathematics and Natural Sciences and then by the "Teacher's Council" (Lärarrådet), a 
body that included all staff professors and college management, but no consensus could be reached. The Faculty recommended Troedsson, depicted as a skilled generalist with extensive teaching experience (and of course already a member of the staff), while the council, including the humanities, with some reservation recommended von Post, mainly citing arguments from the positive expert reviews. In the meantime, the college received additional letters from two of the applicants (Troedsson and von Post) and one of the experts (Holtedahl), and even a missive from a professor of palaeontology (Erik Stensiö) who was not part of the process but wanted to clarify a few things and thereby influence the outcome.

When the time came to make the final decision, the university board found itself in a tricky situation. Whom should they trust: the external experts, the internal experts at the faculty or the college at large? Some of the board members called for additional external expertise and the chair of the university board had apparently also talked to a number of other senior professors in confidence. Eventually the board was called to vote and with six votes for and two against, it was decided that von Post should be offered the position. One of the two naysayers, Member of Parliament Carl Lindhagen, stated (in a letter later added to the board proceedings) that the decision was deeply problematic, insinuating that some of the external experts had been biased and that some other senior geologists in Sweden had different views about von Post's general competence. But this statement had no impact on the decision. In August 1929, von Post finally became Professor of General and Historical Geology at Stockholm University College, a position he retained until his death in 1951.

\section{The aim of pollen statistics was to tackle both botanical and geological questions}

Through five decades of research in the field, von Post significantly increased knowledge of postglacial marshlands and peat bogs and their stratigraphy, and used this knowledge in the interpretation of shoreline displacement, vegetation history and historical climate change. To the general Swedish public, he also became familiar as a popular writer on geological matters, landscape history and more. Like many of his colleagues in the Quaternary geology enterprise, von Post contributed to historical biogeography and archaeology (Lundqvist 1951, 1996; Selling 1951), though neither a professional biologist nor an archaeologist. Von Post was, first and foremost, a geologist. Although indeed interested in vegetation history and ancient cultures, geology was his passion and his mission. As his student Erdtman put it, "He loved geology. He loved it most intensely" (1967, p 25).

Hence, von Post managed to do many things, but his most important contribution to science was his version of pollen analysis. The basic notion behind this method, initially dubbed "pollen statistics", was that peat bogs were archives that stored an enormous amount of preserved tree pollen that could be utilized as data, which in turn could be linked to other data about the past (von Post 1928; Nordlund 2014). According to von Post, it was only possible to use fossil material as reliable data for systematic geological studies if the material was represented in great quantity, and if the fossils remained unaffected by the "archive". In this respect, fossil pollen was much more useful than the single macrofossils from the trees and plants used previously to trace landscape and climate changes (von Post 1918).

Naturally, this idea did not just come to him out of the blue. Microscopic morphological identification of the various species of tree pollen had been going on for a long time and fossilized pollen from postglacial deposits had been utilized previously in Germany, Denmark, Finland and Sweden, notably by the botanist Gustaf Lagerheim (1860-1926), who worked closely with the Swedish Geological Survey, conducting analyses of botanical content in soil and peat bogs (e.g. Selling 1951; Manten 1967). Inspired by Lagerheim, von Post argued as early as 1909 that it would be possible to surmise the presence of bygone spruce forests by using not only macrofossils but also, as a complement, spruce pollen fossils preserved in Swedish peat bogs (von Post 1909). In acknowledgement of this collaboration, Erdtman (1967, p 25) later argued that the approach should be called "the pollen-analytical method according to Lagerheim and Von Post".

It was first and foremost the introduction of the "pollen diagram" with which to calculate and visualize the findings - the statistically based amount of pollen from different species in relation to each other at different depths - that established von Post's contribution to pollen analysis as a quantitative geological method. The advantage of the pollen diagram was that it summarized a large amount of data and the chronological and spatial relationships between the different species detected. It was now also possible to relate visually the changing plant communities to geological and climatological changes in the past.

The goal of pollen statistics was ultimately to develop the empirical study of peat bogs-and their chronologyfrom a Quaternary point of view and produce knowledge significant to the interpretation of landscape and climate change after the latest Ice Age. In essence, the pollen diagram was designed to serve as a means of determining geological time-a crucial aspect of the Quaternary geology enterprise (von Post 1918, 1924). Thus it is not surprising that the first printed diagrams appeared in a journal aimed at geologists, namely the Bulletin of the Geological Institution of the University of Uppsala (von Post 1916), published by von Post's alma mater.

In the proceedings from the 1916 conference, three diagrams of two different types were presented, including one 
regional average diagram. These diagrams were based on a relatively limited amount of material, and von Post stressed that the results were thus only tentative (von Post 1918). This attitude is not surprising. Field scientists of this era were trained not to extrapolate and speculate but to rely heavily on field data. The gathering of a massive amount of data was necessary to sustain any claim in a project as complex as interpreting landscape and climate change (Sörlin 2009). A few years later, at the 17 th Convention of Naturalists in Gothenburg in 1923, von Post was able to present far more detailed maps. By then, the amount of collected and analysed pollen was so extensive that it was possible to trace some general changes, at least regarding the postglacial history of the southern parts of Sweden (von Post 1924). A collection of more than 50,000 microsamples from various peat bogs was now at his disposal. But where had they come from?

\section{Pollen statistics was facilitated by a geological peat bog inventory}

As I have argued elsewhere (Nordlund 2014), a large portion of the samples von Post used was linked to a geological peat bog inventory conducted in southern Sweden by the Swedish Geological Survey in the 1910s and 1920s. Its impetus was financial and political, intended to create a domestic peat industry and thereby secure access to domestic energy resources (Andersson and Santesson 1913). It began on a small scale in 1912 and was expanded 5 years later thanks to increased government funding. As many as 25 assistants per year, mainly enthusiastic young science teachers and students of geology and botany (including Erdtman), participated in the project. The director in charge of conducting the inventory was the Survey's in-house peat bog expert, Lennart von Post (von Post 1922; Lundqvist 1996).

Obviously, the reason for the increase in the Survey's budget was the outbreak of the First World War. Sweden was, and still is, a country without its own oil and coal resources and the war made acute the necessity of a secure domestic energy supply. Peat bogs on the other hand are plentiful throughout the country and their exploitation was seen as a possible solution, along with wood and cellulosic ethanol (Egan Sjölander et al. 2014). The peat industry expanded rapidly and employed over 6,000 workers at a total of 136 factories by its peak in 1918 (Runefelt 2008).

The peat bog inventory was conducted according to two simultaneous plans. The aim of the first was to systematically chart the total number of bogs in different localities along parallel lines; the aim of the second was to estimate the practical possibility of exploitation (Gavelin and von Post 1916). The task was both to measure the volume of the bogs and to analyse their profiles with core samples extracted with a special bog drill (Instruktion 1918). Samples for microscopy were stored at the Geological Survey in a dedicated archive. These samples and their pollen content were then analysed in a laboratory setting during the winter season. In this way, field science and lab science were integrated in a new way.

Analysing and quantifying pollen was tricky and time consuming work, but luckily von Post had skilled assistants, including Tofsy Guldbrand (1895-1990), who not only worked side-by-side with him but also became his wife (von Post 1924, 1967). Connubial bliss was not unheard of in the laboratories of Stockholm; von Post's forerunner, Professor De Geer, married his assistant Ebba Hult (1882-1969) in 1908, and Professor of Chemistry and Nobel laureate Hans von Euler-Chelpin (1873-1964) married his assistant Elisabeth Baroness af Ugglas (1887-1973) in 1913. Many renowned scientists benefitted from the yeoman work of female counterparts in both the household and the laboratory who never received public or academic acknowledgement, thus fading into undeserved obscurity (e.g. Fara 2004; Lykknes et al. 2012; Bergwik 2016).

Despite these efforts, the peat bog inventory was never completed according to plan. Due to the economic downturn experienced by Sweden in the early 1920s, the government needed to save money and the inventory was interrupted. Enormous quantities of data were collected-in sum 21,000 pages of protocol and 56,000 samples — but in the end only thirteen of 60 planned peat bog maps were completed, and only one out of three planned volumes of findings was published (von Post and Granlund 1926; Selling 1951; Lundqvist 1996). Nor did the inventory have much of an impact on the welfare of the nation. After the war, cheap coal and later oil could be readily imported from abroad. Furthermore, hydro-electric power generation became common.

Yet, knowledge about the types and distribution of peat bogs had increased dramatically, and a detailed map was produced. In addition, the inventory propelled the evolution of pollen statistics and pollen analysis as a basic scientific method, as the samples it produced comprised the empirical foundation of von Post's analytical efforts. As already stated in the paper presented in Kristiania, "The material [for my systematic investigation] was taken from the archives of peat bog-profiles at the Swedish Geological Survey, from samples that had been collected over the course of time, many of them in connection with experimental work related to a planned statistical inventory of the quantity of available peat in South Sweden" (von Post 1918, p 384). And in the Gothenburg paper of 1923 we read, "With few exceptions the samples used are taken from the collection of microscopic samples produced during the Swedish Geological Survey's ongoing peat bog inventory" (von Post 1924, p 86). On the other hand, the design of the inventory restricted the scope of the fieldwork and in turn shaped von Post's scientific 
results. If puzzled as to why all von Post's early pollen diagrams were based solely on field work in southern Sweden, the simple answer is that the inventory was conducted only in that part of the country, where the peat industry was intended to flourish.

\section{Pollen statistics was not accepted without criticism}

Von Post's pollen statistics and diagrams gave rise to critical inquiry. One issue was the fact that the diagram showed relative (percentage) values and not the absolute number of pollen grains; another was how the pollen curves were to be presented visually and interrelated chronologically. Initially, von Post constructed composite diagrams with overlapping taxon curves, but he later also used resolved diagrams where each taxon was presented separately. Producing diagrams that visualized the evolution of nature (and sometimes also culture) in the postglacial periods was already a common practice of Quaternary geology, but von Post's pollen diagrams looked quite different (Nordlund 2001b). Unfortunately, von Post does not say much about his creative process or why he designed the diagrams the way he did. If he indeed had a model that inspired him it may have been De Geer's profiles of the thickness of varved clay. It is known that De Geer's "objective geological chronology" made a strong, early impression on him (von Post 1910). Von Post continued to follow the development of geochronology and after De Geer's death in 1943 even became acting director of the Geochronological Institute (Bergwik 2016, p 150).

Another question had to do with credibility-were peat bogs trustworthy "archives"? Returning from Kristiania in 1916 to present his ideas to the Geological Society in Stockholm, von Post met with mixed reactions. Some, like Gerard De Geer, felt that the new method was, as he put it, "a most promising idea for Quaternary geology" (Mötet den 2 November 1916, p 394). Others were more sceptical. The main question was whether the analysed pollen grains were derived from the investigated areas in question or if they had spread from remote locations and thus "infected" the archives.

To prove the significance of long-distance migration, botanist Henrik Hesselman (1874-1943) arranged a pollen experiment in the field. During the summer of 1918, he had collection basins placed on two light vessels in the Baltic Sea, at 30 and $55 \mathrm{~km}$ from the mainland, respectively. Day after day, wind-borne pollen was collected and preserved for later analysis, with one site collecting more than 100,000 grains of pollen and the other over 50,000.

At a meeting of the Geological Society in 1919, Hesselman confronted von Post with his results and stated, "We have been prone to underestimate the role played by migrating pollen in our peat bogs"; in other words, the archives could indeed be infected by pollen from remote places at the whim of wind and topography (Mötet den 6 Februari 1919, p 99). So, how could von Post really know which pollen to count? He replied that migrated pollen was of no real significance to the total amount, which had accumulated for thousands of years in the peat layers. Of no significance, at least from a geological point of view (Mötet den 6 Februari 1919, p 99).

This exchange demonstrates the fact that von Post's pollen statistics were not unanimously embraced when launched. This is, however, not surprising. When a scientist proposes a grand new idea that challenges established practices, it is not uncommon that he or she is met with resistance and critique (e.g. Barber 1961; Kuhn 1970). Aspects of the questions Hesselman raised, on how pollen gets to a place of sedimentation and the calculation of pollen numbers as well as attempts to compare diagrams from different localities, continued to be discussed (e.g. Fagerlind 1949), but his criticism was never a real obstacle to the general acceptance of the method. It was successively incorporated into the geologist's (as well as botanist's and archaeologist's) toolbox as one of many methods for the empirical study of past landscapes, climate history and chronology. In the 1920s-when von Post applied for his professorship - the method also travelled abroad thanks to his students, notably Erdtman (1921, 1943), and it continued to evolve as it was tested and found useful by scientists in Norway, Denmark, Finland, Russia, Germany, and America (Selling 1951, p 282). The effective time span was also extended, from the Quaternary back to the Tertiary Period.

\section{Conclusions}

In this essay, I have made four points about Lennart von Post and the relationship between Quaternary geology and the early history of quantitative pollen analysis. My first point is that von Post was not a botanist, ecologist, archaeologist or palynologist but simply a geologist who, when he invented pollen statistics as a method, was working for the Swedish Geological Survey as a peat bog expert. His identity as geologist did not waver much over time and he ended his scientific career as professor of General and Historical Geology at Stockholm University College, obtaining his position in open competition with other skilled and wellknown geologists. None of the external experts or professors at the College questioned von Post's qualifications as a Quaternary geologist. Yet, some thought that his expertise was too specialized for a chair that included both historical and general geology.

Second, even though pollen analysis produced knowledge about past vegetation and plant communities, von Post did not see this strictly as an end in itself; it was also a means 
with which to tackle heady geological issues, such as the determination of geological time.

Third, although von Post was single author of the papers that included the first pollen diagrams and one of two authors of the major book on Swedish peatbogs, the making of these diagrams, maps and texts benefitted from collective work: field work in the service of the Government and peat industry and laboratory work in which von Post's soon-to-be wife participated (Tofy Guldbrand von Post).

Fourth, although the approach eventually achieved global scientific recognition, quantitative pollen analysis was not accepted without criticism, taking some years to break through beyond the Geological Survey. If von Post had published more in German or English, if he had participated in more international conferences, if he had a position at a university where he could train graduate students, and if he had summarized his work in a general textbook published abroad, this breakthrough would probably have occurred earlier.

Acknowledgements This essay expands on my presentation at the symposium "Centenary (1916-2016) of Pollen Analysis and the Legacy of Lennart von Post", held at the Royal Swedish Academy of Sciences in November 2016. The presentation was partly based on my article Peat Bogs as Geological Archives: Lennart von Post et al. and the development of quantitative pollen analysis during World War I, published in the journal Earth Sciences History in 2014. I thank the organizers of the symposium for inviting me as speaker, the Swedish National Archives in Stockholm for assistance in finding von Post's papers, the two reviewers for their comments on the manuscript, and Stephen Fruitman for language editing.

Open Access This article is distributed under the terms of the Creative Commons Attribution 4.0 International License (http://creativecommons.org/licenses/by/4.0/), which permits unrestricted use, distribution, and reproduction in any medium, provided you give appropriate credit to the original author(s) and the source, provide a link to the Creative Commons license, and indicate if changes were made.

\section{References}

Andersson JG, Santesson H (1913) Förslag från Sveriges Geologiska Undersökning om en utredning af Sveriges torftillgångar. Sven Mosskulturfören Tidskr 27:50-59

Barber B (1961) Resistance by scientists to scientific discovery. Science 134:596-602

Bergwik S (2016) Kunskapens osynliga scener: Vetenskapshistorier 1900-1950. Makadam, Göteborg

Brown JH (1991) New approaches and methods in ecology. In: Real LA, Brown JH (eds) Foundations of ecology: classic papers with commentaries. University of Chicago Press, Chicago, pp 445-455

Edwards KJ, Fyfe RM, Jackson ST (2017) The first 100 years of pollen analysis. Nat Plants 3:1-4

Egan Sjölander A et al (2014) Motorspriten kommer: en historia om etanol och andra alternativa drivmedel. Gidlunds, Möklinta

Erdtman G (1921) Pollenanalytische Untersuchungen von Torfmooren und marinen Sedimenten in Südwest-Schweden. Almqvist \& Wiksell, Stockholm
Erdtman G (1943) An introduction to pollen analysis. Chronica Botany Company, Waltham

Erdtman G (1967) Glimpses of palynology 1916-1966. Rev Palaebot Palynol 1:23-29

Eriksson G (1978) Kartläggarna: Naturvetenskapens tillväxt och tillämpningar i det industriella genombrottets Sverige 1870-1914. Umeå University, Umea

Fagerlind F (1949) Some reflections on the history of the climate and vegetation of the Hawaiian islands. Sven Bot Tidskr 43:73-81

Fara P (2004) Pandora's breeches: women, science and power in the enlightenment. Pimlico, London

Frängsmyr T (1976) Upptäckten av istiden: studier i den moderna geologins framväxt. Swedish History of Science Society, Stockholm

Gavelin A, Von Post L (1916) En förrådsstatistisk undersökning av torvmarkerna inom Götaland och Svealand utom Dalarna. Swedish Geological Survey, Stockholm

Instruktion (1918) Instruktion för förrättningsmännen vid Sveriges Geologiska Undersöknings förrådsstatistiska Torvmarksundersökning. PA Norstedt \& Söner, Stockholm

Kohler R (2002) Landscapes and Labscapes: exploring the lab-field border in biology. University of Chicago Press, Chicago

Kristiansen TA (2017) Meteorologi på reise: Veivalg og impulse i Arnt Eliassen og Ragnar Fjørtofts forskerkarrierer. University of Bergen, Bergen

Kuhn TS (1970) The structure of scientific revolutions, 2nd edn. University of Chicago Press, Chicago

Lundqvist G (1951) Lennart von Post 16.6.1884-11.1.1951. In: Svensk geografisk årsbok 27. Sydsvenska Geografiska Sällskapet, Lund, pp 96-106

Lundqvist J (1996) Von Post, Ernst Jakob Lennart. In: Svenskt biografiskt lexikon 144. Svenskt Biografiskt Lexikon, Stockholm, pp 480-487

Lykknes A, Opitz DL, Van Tiggelen B (2012) For better or for worse? Collaborative couples in the sciences. Birkhäuser, Heidelberg

Manten AA (1967) Lennart von Post and the foundation of modern palynology. Rev Palaeobot Palynol 1:11-22

Mötet den 2 November (1916) Geologiska Föreningen i Stockholms Förhandlingar 38:383-394

Mötet den 6 Februari (1919) Geologiska Föreningen i Stockholms Förhandlingar 41:89-108

Nordlund C (2001a) Det upphöjda landet: vetenskapen, landhöjningsfrågan och kartläggningen av Sveriges förflutna, 1860-1930. Royal Skyttean Society, Umea

Nordlund C (2001b) Bildens betydelse: om vetenskapliga visualiseringar av det postglaciala landskapets utvecklingshistoria. VEST $13: 7-26$

Nordlund C (2007) Between science and industry: on the establishment, organisation and practices of the Swedish Geological Survey in the 19th Century. Earth Sci Hist 26:127-149

Nordlund C (2014) Peat bogs as geological archives: Lennart von Post et al. and the development of quantitative pollen analysis during World War I. Earth Sci Hist 33:187-200

Oldroyd D (2006) Earth cycles: a historical perspective. Greenwood Press, Westport

Runefelt L (2008) Torvbubblan 1900-1925. In: Runefelt L (ed) Svensk mosskultur: odling, torvanvändning och landskapets förändring 1750-2000. Royal Swedish Academy of Agriculture and Forestry, Stockholm, pp 329-357

Selling OH (1951) Lennart von Post 16/6 1884-11/1 1951. Sven Bot Tidskr 45:275-296

Sörlin S (2009) The global warming that did not happen: historicizing glaciology and climate change. In: Sörlin S, Warde P (eds) Nature's end: history and the environment. Palgrave Macmillian, Houndmills, pp 93-114 
Sörlin S (2011) The anxieties of a science diplomat: field coproduction of climate knowledge and the rise and fall of Hans Ahlmann's 'Polar Warming'. In: Fleming JR, Jankovic V (eds) Klima. Osiris 26. University of Chicago Press, Chicago, pp 66-88

Von Post L (1909) Stratigraphische Studien über einige Torfmoore in Närke. Geol Fören Stockh Förh 31:629-706

Von Post L (1910) En exakt geologisk tideräkning. Popul Nat Rev 1:11-20

Von Post L (1916) Einige südschwedischen Quellmoore. Bull Geol Inst Univ Uppsala 15:219-278

Von Post L (1918) Skogsträdpollen i sydsvenska torvmosselagerföljder. In: Forhandlinger ved de skandinaviske naturforskeres 16. Møte i Kristiania den 10-15. Juli 1916. Skandinaviska Naturforskaremöten, Kristiania, pp 432-465

Von Post L (1922) Sveriges Geologiska Undersöknings torvinventering och några av dess hittills vunna resultat. Sven Mosskulturfören Tidskr 36:1-27
Von Post L (1924) Ur de sydsvenska skogarnas regionala historia under postarktisk tid. Geol Fören Stockh Förh 46:83-128

Von Post L (1928) Pollenstatistik. In: Jägerskiöld J, Perhson T (eds) Naturens liv i ord och bild. Strövtåg och upptäckter inom Nordens växt- och djurvärld, Vol 2. Natur \& Kultur, Stockholm, pp 612-628

Von Post L (1929) Den postglaciala landsänkningen. Nord Tidskr Vetensk Konst Ind 5:506-525

Von Post L (1967) Forest tree pollen in South Swedish peat bog deposits, translated by Margaret Bryan Davis and Knut Fægri. Pollen Spores 9:378-401

Von Post L, Granlund E (1926) Södra Sveriges torvtillgångar 1. Swedish Geological Survey, Stockholm 